\title{
Strategi Gay dalam Mencari Pasangan Pertama Studi Kasus Lima Orang Mahasiswa Gay di Kota Padang
}

\author{
Wahyu Ikhsan Hadley ${ }^{1}$, Erianjoni Erianjoni ${ }^{2}$ \\ 1,2 Universitas Negeri Padang \\ Email: thisismrhadley@gmail.com, erianjonisosiologi@gmail.com
}

\begin{abstract}
Abstrak
Penelitian ini mengkaji mengenai strategi gay dalam mencari pasangan pertama studi kasus lima orang mahasiswa gay di Kota Padang. Dalam mencari pasangan, pada saat pertama seorang gay memiliki strategi dan cara cara khusus untuk mendapatkan pasangan. Penelitian dilakukan dengan pendekatan kualitatif, jenis penelitian studi kasus. Teknik pemilihan informan dengan snowball sampling. Data dikumpulkan melalui observasi, wawancara mendalam, dan studi dokumen. Untuk mendapatkan keabsahan data dilakukan triangulasi sumber, teknik dan waktu. Data dianalisis dengan model interaktif dari Miles dan Huberman. Temuan penelitian ini adalah strategi gay mencari pasangan pertama studi kasus lima orang mahasiswa gay di Kota Padang: (1) mencari pasangan melalui media sosial; (2) mencari pasangan dengan mengunakan jasa dari pihak ketiga; (3) mencari pasangan dengan cara membangun hubungan menggunakan uang.
\end{abstract}

Kata Kunci: Strategi, Gay, Pasangan

\begin{abstract}
This study examines gay strategies in finding the first pair of case studies of five gay students in the city of Padang. In looking for a partner, at the first time, gays have strategies and specific ways to get a partner. The study was conducted with a qualitative approach, a type of case study research. The technique of selecting informants with snowball sampling. Data is collected through observation, indepth interviews, and document studies. To get the validity of the data, triangulation of sources, techniques and time is done. Data were analyzed by interactive models from Miles and Huberman.The results of this study are that gay strategies to find the first partners of five gay students in the city of Padang: (1) looking for partners through social media; (2) looking for a partner by using services from a third person (3) looking for a partner by building relationships using money.
\end{abstract}

Keywords: Strategy, Gay, Partner 


\section{Pendahuluan}

Orientasi seksual merupakan variasi yang terjadi didalam perkembangan seksual individu yang akan berkembang sesuai dengan kondis lingkungan Manusia pada dasarnya sudah memiliki potensi untuk menjadi homoseksual dan heteroseksual, terjadinya orientasi seks homoseksual, dan heteroseksual ataupun biseksual tersebut dipengaruhi oleh banyak sebab, seperti pengalaman dimasa kecil, pengaruh dari lingkungan, dan juga pengaruh dari keluarga. Oleh karena itu tidak menutupi kemungkinanan seseorang akan memiliki orientasi homoseksual. Homoseksualitas mengacu pada interaksi seksual terhadap sesama jenis, yang mana homoseksual ini dibagi menjadi dua bagian yaitu gay dan lesbian atau lesbi. Gay merupakan istilah untuk seseorang homoseksual pria yang memiliki kecenderungan seksual kepada sesama pria atau disebut juga dengan pria yang mencintai pria, baik secara fisik, seksual, emosional ataupun secara spiritual. Beren (2013) menyatakan bahwa homoseksualitas pada pria terjadi di seluruh lapisan masyarakat dunia dengan perkiraan $21 \%$ pria di dunia adalah gay. Permasalahan homoseksualitas ini tekait juga dengan keinginan pemenuhan hasrat seksualitas gay yang mana hanya akan terpenuhi oleh individu dengan jenis kelamin yang sama. Menurut Savin-Williams (Savin,1996: 178), seorang gay dewasa dini juga melakukan aktivitas yang sama seperti yang terjadi kaum straight seperti keinginan untuk memiliki pasangan atau pacar.Membentuk dan mengembangkan hubungan pacaran sebagai suatu hal yang penting bagi dewasa dini dilakukan oleh semua orang tanpa memilihat orientasi seksual tertentu, hal tersebut terbukti dalam penelitian mereka yang bahwa gay dewasa dini juga membentuk hubungan pacaran dengan pasangannya, hubungan pacaran akan membantu seorang gay dalam pencarian identitas diri sebagai seorang gay, dan membentuk gay merasa lebih lengkap. Gay yang memiliki pacar akan memiliki harga diri yang lebih tinggi, penerimaan diri yang lebih tinggi, dan akan lebih terbuka kepada lingkukan mengenai identitas diri sebagai seorang gay.

Dalam pencarian pasangan seorang gay akan berhadapan dengan nilai dan norma yang berlaku dalam masyakat yang mana didalam nilai dan norma yang ada pada masyarkat saat ini adalah menyatakan homoseksualitas itu adalah sesuatu yang menyimpang, dianggap tabu dan merupakan hal yang memalukan. Ada banyak reaksi dari masyarakat menanggapi permasalahan ini, baru-baru ini terjadi penolakan yang dilakukan oleh mahasiswa di salah satu perguruan tinggi di Kota Padang, yang dalam aksi yang mereka lakukan mereka menyuarakan bahwa LGBT yang di dalamnya juga termasuk kaum gay merukan aib yang akan mendatangkan bencana dan kemudoratan sehingga mereka menentang keras tentang keberadaan LGBT di kota mereka. Selain itu beberapa waktu lalu wakil Wali Kota Padang juga pernah mengatakan dalam pidatonya yang dimuat dalam salah satu surat kabar lokal, bahwa pemerintah Kota Padang akan menyusun dan membentuk peraturan daerah yang mana dalam perda tersebut berisi tentang pelarangan serta hukuman yang akan diberikan kepada kaum LGBT yang ada di kota Padang.

Penolakan penolakan yang terjadi dimasyarkat menjadi salah satu hambatan bagi seorang gay dalam mencari pasangan, karena label yang diberikan oleh masyarakat kepada gay merupakan gambaran dari sikap masyarakat terhadap mereka. Hal-hal seperti itu menjadi salah satu pembatas pergerakan gay dalam mencari pasangan, kaum gay juga dibatasi oleh nilai dan norma. Oleh sebab itu demi mendapatkan pasangan seorang gay memiliki cara dan strategi serta teknik dalam mencapai tujuan mereka.

Beberapa studi relevan yang terkait dengan penelitian ini adalah pertama oleh (Yogi Saputra. 2017. Http://prezi.com/m/fj5gqbrgr/gerakan-sosial-komunitas-gay-di-kota-padang/. Diakses tanggal 21 sepeter 2018 ) mengenai gerakan sosial gay di Kota Padang. Hasil penelitiannya menunjukkan alasan para gay membentuk gerakan komunitas Pelangi Andalas Group yang terdapat di Kota Padang. Gerakan ini melakukan aksi secara damai dan diam diam. Karena adanya larangan dari pemerintah Provinsi Sumatera Barat yang melarang 
keberadaan gay di wilayahnya. Penelitian dari (Gesti Lestari, 2012Http://Eprints.uny.ac.id. Diakses Tanggal 21 Septerber 2018) mengenai fenomena homoseksual di Yogyakarta. alasan seseorang memilih jalan hidup sebagai seorang homoseksual diantaranya adalah karena kebutuhan seksual yang mana dirasankan oleh kaum homoseks atau gay hanya bisa tertarik dengan sesama jenis laki-laki saja, trauma percintaan dengan lawan jenis yang dirasakan cukup dalam oleh laki-laki sehingga memilih pasangan yang sejenis dengan harapan rasa sakitnya tidak terulang dan pengalaman seks yang kurang menyenangkan (sodomi) menyebabkan trauma berkepanjangan.

Berbeda dengan penelitian di atas, dalam penelitian ini lebih fokus untuk melihat strategi yang digunakan oleh gay pada saat pertama kali mencari pasangan. Seorang gay akan memiliki stategi, teknik atau cara cara dalam mencari seorang pasangan, karena keberadaan gay adalah sesuatu yang dianggap menyimpang dan ditolak oleh masyarakat pada umumnya. Berdasarakan hal tersebut, maka yang menjadi pertanyaan dalam penelitian ini adalah: bagaimana strategi yang digunakan oleh seorang gay dalam mencari pasangan pada saat pertama kali. Penelitian ini bertujuan untuk menjelaskan strategi serta cara cara yang digunakan oleh seorang gay pada saat pertama mencari pasangan studi kasus pada 5 orang mahasiswa gay di Kota Padang.

Penelitian ini secara teoritis bermanfaat sebagai sebuah dokumen tertulis mengenai strategi gay dalam mendapatkan pasangan pada saat pertama kali. Secara praktis untuk memberikan wacana dan dapat dijadikan referensi untuk melanjutkan penelitian selanjutnya.

Penelitian ini dianalisis dengan teori aksi yang dikemukakan oleh Talcott Parsons, Parsons berpendapat bahwa aksi atau action yang dilakukan oleh seseorang bukanlah sebuah perilaku atau behavior. Aksi adalah tanggapan atau respon seseorang terhadap suatu stimulus dan bukanlah sikap yang lahir dari perulangan yang dilakukan aktor didalam hidupnya melainkan aksi adalah sikap yang disebut Parsons dengan voluntarisme yaitu suatu sikap atau kemampuan seorang aktor dalam menentukan pilihanyan, hal ini melalui pemikiran yang telah dilakukan oleh sang aktor sebelumnya.

Parsons (2014) merumuskan unsur dasar dari tindakan sosial adalah seorang individu adalah sebagai aktor, seorang aktor adalah pemburu tujuan tujuan yang ingin dicapai, seorang aktor memiliki alternatif cara serta alat untuk mencapai tujuannya, seorang aktor dibatasi dengan sejumlah kondisi dan situasi yang menjadi pembatasnya, pilihan pilihan cara yang digunakan oleh aktor diarahkan oleh nilai dan norma, tetapi keputusan akhir yang ditentukan oleh kemampuan aktor dalam memilih atau disebut juga dengan voluntarisme.

Seorang gay yang memiliki keinginan untuk memiliki pasangan akan menciptakan dan mengunakan strategi-strategi yang mereka gunakan untuk mendapatkan pasangan, cara cara dan alat yang mereka gunakan merupakan bagian dalam mencapai tujuan mereka yaitu mendapatkan pasangan, keberadaan dan inginan gay dalam memiliki pasangan akan sangat dipengaruhi oleh nilai dan norma yang ada didalam masyarakat, tetapi keputusan akhir tetap ditentukan oleh gay tersebut.

\section{Metode Penelitian}

Pendekatan dalam penelitian ini adalah kualitatif, yaitu suatu pendekatan yang menjelaskan realitas sosial yang diteliti secara mendalam. Jenis penelitiannya adalah studi kasusyaitu menelaah mengenai suatu keadaan masyarakat yang dilihat dari persoalan atau kasus tertentu, baik dalam suatu lembaga, kelompok maupun individu. Teknik pemilihan informan dengan snowball sampling dengan informan penelitian berjumlah 15 orang, diantaranya; 5 orang mahasiswa gay di pergunuan tinggi Kota Padang 4 orang mahasiswa pengguna media sosial yang pernah memiliki pengalaman dikontak oleh gay melalui media sosial yang mereka gunakan, 3 mahasiswa heteroseksual yang memiliki hubungan perteman 
dengan mahasiswa gay, serta 4 orang mahasiswa yang pernah membantu menjodohkan seorang gay dengan calon pasangannya

Teknik pengumpulan data dilakukan melalui observasi, wawancara mendalam, dan studi dokumen. Pengamatan dilakukan terhadap 5 orang mahasiswa gay di Kota Padang. Kemudian melakukan wawancara mendalam kepada siswa tersebut, serta dokumen yang membantu penulis untuk mendapatkan informasi penelitian.

Untuk mendapat keabsahan data dilakukan triangulasi. Data yang sama dikumpulkan dari objek yang berbeda. Triangulasi yang digunakan yaitu triangulasi sumber, teknik dan waktu. Dalam melakukan analisis data penulis menggunakan model analisis interaktif dari Miles dan Huberman melalui tiga langkah yang dilakukan secara berkesinambungan selama proses penelitian yaitu reduksi data, penyajian data, dan penarikan kesimpulan.

\section{Hasil dan Pembahasan}

\section{Strategi gay dalam mencari pasangan}

Seorang gay yang memiliki keinginan untuk memiliki pasangan pada saat pertama kali akan menciptakan dan mebentuk serta mengunkan strategi dan cara-cara untuk mencapai tujuannya, bentuk bentuk strategi yang mereka gunakan berupa mencari pasangan melalui media sosial, mencari pasangan menggunakan jasa dari pihak ketiga atau mak comblang, strategi lain adalah dengan menggunakan uang untuk membangun kedekatan dengan calon pasangan.

Pertama, mencari pasangan melalui media sosial, strategi ini yang digunakan oleh seorang gay pada saat pertama kali memiliki keinginan untuk memiliki pasangan, dengan menggunakan media sosial seorang gay merasa aman akan identitas dirinya, mereka biasa mengunakan media sosial yang biasa digunakan orang-orang pada umumnya, seperti instagram, facebook, bahkan mereka juga menggunakan media sosial yang dikhususkan untuk para gay mencari pasangan seperti hornet, blued, grindr.

Mencari pasangan melalui media sosial adalah cara yang dirasa paling aman bagi seroang gay, dikarenakan mereka bisa menutupi identitas diri mereka dengan menggunakan akun palsu atau nama palsu serta photo palsu, agar tidak bisa diketahui oleh semua orang, melalui media sosial ini mereka juga bisa menyeleksi calon pasangan terbaik yang mereka inginkan dengan cara mengikuti dan terus memantau kegiatan yang dilakukan calon pasangan di media sosial tersebut, seorang gay juga menggunakan aplikasi khusus gay, sehingga mereka bisa lebih leluasa dalam mencari pasangan yang sudah jelas juga merupakan seorang gay.

Berdasarkan penejlasan di atas dapat diketahui bahwa seorang gay yang memiliki keinginan untuk mencari pasangan pada saat pertama menggunakan media sosial untuk mencari dan menyeleksi calon pasangan yang meraka inginkan.

Uraian di atas sesuai dengan yang diungkapkan Talcott Parsons dalam teori aksi bahwa seorang individu merupakan seorang aktor memiliki tujuan, dalam mencapai tujuannya seorang aktor memilikialternatif cara dalam mencapai tujuannya, seorang gay memiliki tujuan untuk mendapatkan pasangan, maka dia memiliki alternatif cara dan strategi yang mana dalam kasus ini cara yang digunakan oleh seorang gay tersebut adalah mencari pasangan melalui media sosial, cara ini dianggap cara paling aman untuk mencari tau mengenai calon pasangan, tanpa perlu mengungkapkan jati diri mereka yang sebenarnya.

Kedua, Mencari pasangan dengan menggunakan jasa dari pihak ketiga, bentuk strategi lain yang digunakan oleh seorang gay dalam mencari pasangan pada saat pertama adalah dengan menggunakan jasa dari pihak ketiga yang biasa disebut orang dengan istilah mak comblang, dalam dunia gay mereka memiliki panggilan atau istilah untuk mak comblang 
yaitu mereka menggunakan istilah fudan untuk memanggil mak comblang pria dan istilah fujoshi mereka gunakan untuk memanggil mak comblang wanita.

Jasa dari pihak ketiga disini akan sangat membantu seorang gay dalam mencapai tujuannya mendapatkan pasangan apalagi dalam kasus saat pertama kali mencari pasangan dikarenakan seorang gay belum terlalu terbiasa dengan keadaan dimana dia harus berusaha mendapatkan perhatian dari calon pasangan, karena itu seorang gay membutuhkan bantuan dari pihak ketiga yang dianggap mampu membantu mereka dalam menjalin kedekatan dengan calon pasangan.

Dalam kasus ini pihak ketiga bertugas untuk membangun ketertarikan dari calon pasangan terhadap gay tersebut, mereka biasanya membantu membuat jadwal bertemu antara seorang gay dengan calon pasangan, atau bisa juga dengan cara menceritakan hal hal positif yang akan membentuk ketertarikan dari calon pasangan kepada seorang gay tersebut, jasa dari pihak ketiga akan sangat membantu seorang gay dalam mencairkan suasana dan membantu seorang gay dalam menentukan langkah langkah yang akan mereka pilih dalam bertindak.

Hal ini senada dengan yang dijelaskan Talcott Parsons bahwa dalam mencapai tujuan seorang aktor akan memiliki alternatif cara atau alat serta teknik dalam mencapai tujuan, serta seorang aktor akan dihadapkan dengan situasi yang dapat membatasinya dalam mencapai tujuan, dalam kasus ini alternatif cara yang digunakan seoang gay adalah menggunakan bantuan dari pihak ketiga yang dirasa mampu untuk membantu mereka dalam menjalin kedekatan dengan calon pasangan, dan dalam kasus ini yang menjadi hambatan bagi seorang gay adalah dimana ketidak berpengalamannya seorang gay dalam mencari calon pasangan karena pengalaman ini merupakan pengalaman pertama bagi seorang gay dalam memenuhi keinginananya untuk memiliki pasangan.

Ketiga, Mencari pasangan dengan cara membangun hubungan dengan menggunakan uang. Strategi atau cara ini dianggap adalah cara paling ampuh untuk membentuk ketertarikan dari calon pasangan kepada seorang gay, uang mereka gunakan untuk memenuhi kebutuhan materil dari calon pasangan, seperti menggunakan uang untuk membelikan calon pasangan makanan atau mentraktir calon pasangan, juga menggunakan uang untuk membelikan calon pasangan hadiah-hadiah yang mereka inginkan.

Memanfaatkan uang untuk menarik perhatian dari calon pasangan, seorang gay menggunakan stategi ini secara terus menerus sehingga calon pasangan akan merasa dimanjakan dan akhirnya calon pasangan akan merasa tergantung dengan seorang gay karena apapun kebutuhan mereka akan dipenuhi oleh seorang gay tersebut.

Hal ini juga sesuai dengan yang dijelasakan oleh Talcott Parsons dalam teori aksinya, bahwa seorang aktor memiliki alternatif cara dalam mencapai tujuan, serta tindakan yang dilakukan aktor mengejar tujuan dalam situasi dimana nilai dan norma mengarahkan aktor dalam memilih alternatif cara dan alat untuk mencapai tujuan, tetapi keputusan akhir ditentukan oleh kemampuan aktor dalam memilih. Dalam kasus ini seorang gay memiliki alternatif cara yaitu memanfaatkan uang untuk membangun kedekatan dan ketertarikan dari calon pasangan, serta tindakan atau cara itu dianggap tindak melanggar nilai dan norma karena cara itu hanya berbentuk pemberian atau hadiah yang diberikan oleh seorang gay kepada calon pasangan.

Jika dikaitakan dengan pendapat Parsons tentang teori aksi yang membahas tindakan manusia dalam mencapai tujuan yang melihat bahwa seorang individu merupakan aktor yang memiliki sebuah tujuan dan cara cara untuk mencapai tujuan, seorang aktor juga dibatasi oleh situasi yang dapat menghambat mereka dalam mencapai tujuan, aktor juga berada dalam kendali nilai dan norma akan tetapi pilihan dan keputusan akhir ditentukan oleh kemampuan aktor dalam menentukan pilihan, dapat dilihat dalam kasus strategi yang digunakan gay dalam mencari pasangan bahwa strategi yang mereka gunakan berupa mencari pasangan menggunakan media sosial, mencari pasangan dengan menggunakan jasa pihak ketiga, 
mencari pasangan dengan cara membangun kedekatan dengan menggunakan uang. Hal ini merupakan bentuk dari alternatif cara yang mereka gunakan untuk mencapai tujuannya, kondisi yang membatasi gay disini adalah pandangan dari masyarakat yang mengganggap mereka menyimpang serta keadaan dimana keinginan mereka untuk memiliki pasangan ini merupakan hal yang baru bagi mereka karena dalam kasus ini yang dikaji adalah strategi gay dalam mencari pasangan pertama.

Sebuah studi mengenai pola jaringan prostitusi terselubung di Kota Padang yang dilakukan oleh Erianjoni dan Ikhwan pada tahun 2012 menggambarkan kegiatan prostitusi yang dilakuykan oleh beberapa wanita tuna susila ada juga yang tidak menggunakan mucikari sebagai perantara meraka dalam melakukan prakteknya seperti temapat hiburan malam dan tempat kost (Erianjoni,2012,http://ejournal.unp.ac.id/index.php/humanus/article/view/2159/ $\underline{1805}$, diakses 29 januari 2018).

\section{Kesimpulan}

Strategi gay dalam mencari pasangan pertama studi kasus lima orang mahasiswa gay di Kota Padang adalah pertama mencari pasangan melalui media sosial, hal ini mereka lakukan karena dianggap cara paling aman karena mereka tidak perlu mengungkap jati diri mereka kepada orang banyak karena mereka bisa menggunakan akun palsu atau lansung menggunakan akun yang dikhususkan untuk orang orang gay, kedua mencari pasangan melalui jasa dari pihak ketiga, cara ini mereka gunakan kerana kurangnya pengalaman mereka dalam membangun kedekatan dengan calon pasangan sehingga untuk mempermudah mereka dalam mencapai tujuannya memiliki pasangan mereka menggunakan bantuan dari pihak ketiga atau mak comblang, strategi yang ketiga adalah memanfaatkan uang untuk membangun kedekatan serta ketergantungan dari calon pasangan, karena calon pasangan terbiasa di manjakan oleh pemberian pemberian dari seorang gay maka itu akan menjadikan mereka tergantung dengan seorang gay tersebut, cara ini dipandang efektif bagi gay untuk membangun kedekatan dengan calon pasangan

\section{Daftar Pustaka}

Ritzer, George \& Douglas J. Goodman. (2005). Teori Sosiologi Modern. Jakarta: Prenada Media.

Savin,William. (1996). Ethnie-and sexual-minority youth. Fort Worth: Harcourt Bruce Collage Publishing.

Erianjoni,dan Ikhwan. (2012). Pola dan Jaringan Prostitusi Terselubung Di Kota Padang.Jurnal. Http://Ejournal.unp.ac.id/index.php/humanus/article/view/2159/1805. di akses tanggal 29 Januari 2018 pada pukul 14:27 WIB

Gesti Lestari. (2012). Fenomena Homoseksual di Kota Yogyakarta. Http://Eprints.uny.ac.id. Diakses Tanggal 21 Septerber 2018

Yogi Saputra. (2017). Gerakan Sosial Gay di Kota Padang. http://prezi.com/m/fj5gqbrgr/gerakan-sosial-komunitas-gay-di-kota padang/. Diakses tanggal 21 september 2018 